\title{
Knowledge, Attitude and Practice Study about Complementary Feeding in Mothers with Children Upto 02 Years Age Group in Urban Slums across Bhopal City
}

\author{
Deepti Singh ${ }^{1}$, Sunita Lakhwani², D.P.S. Gaharwar ${ }^{3}$ \\ ${ }^{1,2}$ Associate Professor, Department of Paediatrics, R.K.D.F. Medical College Hospital \& Research Centre, Bhopal, ${ }^{3}$ Assistant Professor, Department of Paediatrics, \\ R.K.D.F. Medical College Hospital \& Research Centre, Bhopal.
}

\section{Abstract}

Background: Objective of our study was to assess the knowledge, attitude and practice of complementary feeding among mothers in various Urban Slums across Bhopal City. Subjects and Methods: A cross sectional study was done about knowledge of mothers with children below 2 years of age with help of pretested self designed questionnaire based interview who are attending Anganwadi Centre \& Slum Areas. Results: In our study most of mothers did not know correct time of starting complementary feeding, they also did not know what food can be given, frequency and amount of complementary feed. Conclusion: Knowledge of Mother's concerning timing of complementary feeding is inadequate and practice and attitude are inappropriate. Majority of them are not aware of the current recommendations. Health education about correct feeding should be given to mothers and family members including appropriate time for complementary feeding initiation, complementary foods, it's preparation and practices to give on proper time and amount and hygiene. It will help to prevent malnutrition, infant and under 5 mortality and morbidity and improve the health status of children. Correct information and guidelines about complementary feeding is not reaching the target population. False beliefs, customs and attitude of the mother tend to wean the child late. Poor breastfeeding and inappropriate complementary feeding practices are the principal proximate causes of malnutrition during the first two years of life. Study Design: Cross Sectional Study

Keywords: KAP, Complementary, Breast Feeding, Knowledge, Attitude, Practice, Urban Slums.

Corresponding Author: Dr. Sunita Lakhwani, Associate Professor, Department of Paediatrics, R.K.D.F. Medical College Hospital \& Research Centre, Bhopal.

Received: September 2019

Accepted: September 2019

\section{Introduction}

World Health Organization (W.H.O), Complementary feeding is the process starting when breast milk alone is no longer adequate to meet the nutritional requirements of infants, \& consequently other foods and liquids are needed, along with breast milk. The change from exclusive breast feeding to family food referred to as complementary. ${ }^{[1]}$

Breast feeding is well renowned while early age to be the best feeding for a neonate. Early breastfeeding within 01 hour and for first 06 months related to child malnutrition \& mortality respectively. ${ }^{[2]}$ In India effective implementation of these interventions is yet to be achieved. Proper initiation $\&$ continuation of breast feeding in children under 06 months is only $46.4 \% .{ }^{[3]}$ To formulate any effective strategy to improve infant nutrition it is imperative to have an insight into existing knowledge, attitude and practices about infant feeding practices existing in the community. ${ }^{[4]}$

\section{Subjects and Methods}

A cross sectional study was conducted at Anganwadi Centre \& Slum Areas of Bhopal between August 2018 to July 2019. Mothers of children age below 2 year of various Urban Slums across Bhopal City were included in the study. Well informed written consent was taken by all mothers, Mothers with older children and non willing to participate were excluded. During study 300 mothers were interviewed through a self designed pre tested structured questionnaire based on extensive literature search and WHO and national guidelines. The questionnaire included socio-demographic variables, starting time for complementary feeding, complementary food, frequency and amount of feed, liquid, semisolid and solid food, homemade or readymade food, their knowledge about hygiene in food preparation and feeding, finger foods. Total thirty two questions were asked in interview. The questions had single as well as multiple correct options, some were open ended and others were with 
options all questions asked by doctors after explaining mother about study.

\section{Inclusion Criteria-}

All mothers living in urban slums, with up to 2 yrs age group child.

\section{Exclusion Criteria-}

1. Visitors to the slums.

2. Mothers with child who is more than 2 yrs of age

3. Sick children, children with serious illnesses or children on medication.

\section{$\underline{\text { Statistical analysis }}$}

Statistical analysis was done by using descriptive and inferential statistics using chi square test. Software used in analysis was SPSS 20.0 version. $\mathrm{P}$ Value $<0.05$ is considered as level of significance.

\section{Results}

Table 1: Comparison of demographic profile to Knowledge of Mothers about Complementary feeding

Table 1A: Education of mothers

\begin{tabular}{|c|c|c|c|c|c|}
\hline \multirow[t]{2}{*}{$\begin{array}{l}\text { Education } \\
\text { of mothers }\end{array}$} & \multirow{2}{*}{$\begin{array}{l}\text { Number } \\
\text { of } \\
\text { mothers }\end{array}$} & \multicolumn{3}{|c|}{$\begin{array}{l}\text { Knowledge of mothers about } \\
\text { complementary feeding }\end{array}$} & \multirow{2}{*}{$\begin{array}{l}\text { P- } \\
\text { Valu } \\
\text { e }\end{array}$} \\
\hline & & Good & Average & Poor & \\
\hline Primary & 84 & 29 & 33 & 22 & \multirow{2}{*}{$\begin{array}{l}0.031 \\
\text { Signi } \\
\text { ficant }\end{array}$} \\
\hline Illiterate & 216 & 27 & 109 & 80 & \\
\hline
\end{tabular}

\section{Table 1B: Number of children}

\begin{tabular}{|c|l|l|l|l|l|}
\hline Number & \multirow{2}{*}{$\begin{array}{l}\text { Number } \\
\text { of } \\
\text { children }\end{array}$} & $\begin{array}{l}\text { of } \\
\text { mothers }\end{array}$ & \multicolumn{2}{|l|}{$\begin{array}{l}\text { Knowledge of mothers about } \\
\text { complementary feeding }\end{array}$} & \multirow{2}{*}{\begin{tabular}{l} 
P- \\
Valu \\
\cline { 3 - 5 }
\end{tabular}} \\
\hline One child & 104 & 15 & 47 & 42 & 0.042 \\
\hline $\begin{array}{l}\text { More than } \\
\text { one child }\end{array}$ & 196 & 24 & 110 & 62 & $\begin{array}{l}\text { Signi } \\
\text { ficant }\end{array}$ \\
\hline
\end{tabular}

$\mathrm{P}$ Value is less than 0.05 , hence it is significantly associated.

\section{Table 1C: Age of Mother}

\begin{tabular}{|l|l|l|c|l|l|}
\hline \multirow{2}{*}{$\begin{array}{l}\text { Age of } \\
\text { mother }\end{array}$} & \multirow{2}{*}{$\begin{array}{l}\text { No. of } \\
\text { mother }\end{array}$} & \multicolumn{2}{|l|}{$\begin{array}{l}\text { Knowledge of mothers about } \\
\text { complementary feeding }\end{array}$} & $\begin{array}{l}\text { P- } \\
\text { Valu } \\
\text { en }\end{array}$ \\
\cline { 3 - 5 } & & Good & Average & Poor & \\
\hline $\begin{array}{l}\text { Below } 30 \\
\text { years }\end{array}$ & 186 & 16 & 91 & 79 & $\begin{array}{l}0.032 \\
\text { Signif } \\
\text { icant }\end{array}$ \\
\hline $\begin{array}{l}30 \text { years } \\
\text { and above }\end{array}$ & 114 & 23 & 58 & 43 & \\
\hline
\end{tabular}

$\mathrm{P}$ Value is less than 0.05 , hence it is significantly associated.

Table 1D: Income / Month
\begin{tabular}{|l|l|l|l|l|l|}
\hline $\begin{array}{l}\text { Income / } \\
\text { Month }\end{array}$ & $\begin{array}{l}\text { Number of } \\
\text { mothers }\end{array}$ & $\begin{array}{l}\text { Knowledge of mothers about } \\
\text { complementary feeding }\end{array}$ & $\begin{array}{l}\text { P- } \\
\text { Valu } \\
\text { e }\end{array}$ \\
\cline { 3 - 5 } & & Good & Average & Poor & \\
\hline $\begin{array}{l}\text { Above } \\
10,000 \text { Rs }\end{array}$ & 89 & 09 & 47 & 33 & $\begin{array}{l}0.96 \\
\text { Not } \\
\text { Signif } \\
\text { icant }\end{array}$ \\
\hline $\begin{array}{l}\text { Below } \\
10000 \text { Rs }\end{array}$ & 211 & 18 & 112 & 81 & \\
\hline
\end{tabular}

$\mathrm{P}$ Value is greater than 0.05 , hence it is not significantly associated.
Table 2: Knowledge of mothers about complementary feeding

\begin{tabular}{|l|l|l|l|l|}
\hline $\begin{array}{l}\text { S. } \\
\text { No. }\end{array}$ & $\begin{array}{l}\text { Complementary } \\
\text { feeding } \\
\text { Knowledge }\end{array}$ & Good & Average & Poor \\
\hline 1 & $\begin{array}{l}\text { Meaning of } \\
\text { complementary } \\
\text { feeding }\end{array}$ & 64 & 156 & 80 \\
\hline 2 & Time to start & 42 & 184 & 74 \\
\hline 3 & Amount of feed & 62 & 174 & 64 \\
\hline 4 & Frequency of feed & 104 & 114 & 82 \\
\hline 5 & Food can be given & 82 & 152 & 66 \\
\hline 6 & Hygine practices & 56 & 116 & 128 \\
\hline 7 & $\begin{array}{l}\text { Liquid, Semisolid } \\
\text { and solid diet }\end{array}$ & 40 & 196 & 64 \\
\hline
\end{tabular}

\section{Discussion}

Exclusive breastfeeding is recommended worldwide as the ideal feeding for first six months of life. For successful lactation, timely initiation of breastfeeding i.e. within $1 / 2 \mathrm{hr}$ of normal delivery and within $4 \mathrm{hrs}$ of caesarean delivery is essential. In fact a recent study from Ghana found that $22 \%$ death among newborn can be prevented if they are given breastfeeding within one hr of birth. ${ }^{[5]}$ In present study only half of the total mothers knew about this fact (57\% urban and $46.7 \%$ rural). Likewise only $63.3 \%$ urban and $40 \%$ rural mothers knew about correct period of exclusive breastfeeding. As far as maximum period of breastfeeding (i.e. up to 2 years) is concerned, only $40 \%$ of urban and $36 \%$ of rural mothers were knowledgeable about it.

The women who had history of antenatal care visit during pregnancy period and post natal visit initiate complementary feeding timely. A study in Ghana, Harar, Tigrai found out that timely initiation of complementary feeding is become higher with antenatal and Post natal, maternal education, antenatal care and Post natal care. ${ }^{[6,7]}$ Mothers who have No post natal visit in Health institution were start early complementary feeding as compared to mothers who have follow up. These finding is supported by study conducted by South West Ethiopia. ${ }^{[8]}$ This is explained Mothers who get Health education and advice on complementary feeding during Post natal visit has great effect $\mathrm{t}$ on the timely initiation of complementary feeding. In this study more than two third 139 (69.5\%) of mothers had history of ante natal care visit during their pregnancy period from which the majority $(59.0 \%)$ have had more than three times. This is higher than study in Uganda that only $47 \%$ of women receive antenatal care coverage. ${ }^{[9]}$ This may be due the low overall antenatal care coverage of in the country.

\section{Conclusion}

Knowledge of Mother's concerning timing of complementary feeding is inadequate and practice and attitude are inappropriate. Majority of them are not aware of the current recommendations. Health education about 


\section{Singh et al; Trnauledge, Attitude and Practice Study abaut Camplementary Feeding}

correct feeding should be given to mothers and family members including appropriate time for complementary feeding initiation, complementary foods, it's preparation and practices to give on proper time and amount and hygiene. It will help to prevent malnutrition, infant and under 5 mortality and morbidity and improve the health status of children. Correct information and guidelines about complementary feeding is not reaching the target population. False beliefs, customs and attitude of the mother tend to wean the child late. Poor breastfeeding and inappropriate complementary feeding practices are the principal proximate causes of malnutrition during the first two years of life.

\section{References}

1. Gupte Suraj. Textbook of Pediatric Nutrition. New Delhi, PeepeePublishers and Distributors, 2006.

2. Patel A.B., Badhoniya N., Khadse S., Senarath U., Agho K.E. \& Dibley
M.J. (2010) Infant and young child feeding indicators and determinants of poor feeding practices in India: secondary data analysis of National Family Health Survey 2005-2006. Food and Nutrition Bulletin 31, 314 333.

3. WHO. Complementary feeding, e-library of evidence3 of nutrition actions, March 4, 2016.

4. Edmond KM, Zandoh C, Dingley MA, Amenga Etega S, Weesee Agyei S, Kirkwood BR. Delayed breastfeeding initiation increases risk of neonatal mortality Pediatrics 2006; 117:e380-86.

5. Yadav RJ and Singh P. Knowledge attitude and practices of mothers about breast feeding in Bihar. Indian J Community Med. 2004;29(3):1301 .

6. Uganda; Statistics, UNICEF Retrieved 20 February 2012.

7. Khanal et al. Determinants of complementary feeding practices among Nepalese children aged 6-23 months. BMC Pediatrics.2013; 13:131.

8. Batal M, Boulghourjian C, Abdullah A and A__ R: breast-feeding and feeding practices of infants in a developing country: a national survey in Lebanon, public health nutrition 2005; 9(3):313-319.

9. Kapil U. and Verma D: Breast-feeding Practices in Scheduled.Caste Community in Haryana State; (1994) Indian Pediatric, 31, p. 1227-1232.

Copyright: (C) the author(s), 2019. It is an open-access article distributed under the terms of the Creative Commons Attribution License (CC BY 4.0), which permits authors to retain ownership of the copyright for their content, and allow anyone to download, reuse, reprint, modify, distribute and/or copy the content as long as the original authors and source are cited.

How to cite this article: Singh D, Lakhwani S, Gaharwar DPS. Knowledge, Attitude and Practice Study about Complementary Feeding in Mothers with Children Upto 02 Years Age Group in Urban Slums across Bhopal City. Asian J. Clin. Pediatr. Neonatol.2019;7(3):28-30.

DOI: dx.doi.org/10.21276/ajcpn.2019.7.3.8

Source of Support: Nil, Conflict of Interest: None declared.
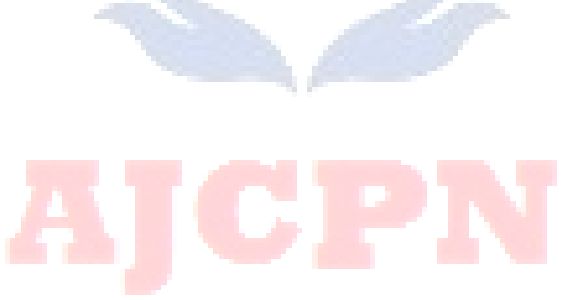